\title{
Learning Achievement Improvement of 1st Grade Students by Using Problem-Based Learning (PBL) on TPACK MODEL
}

\author{
Orathai Chaidam $^{1} \&$ Apantee Poonputta ${ }^{1}$ \\ ${ }^{1}$ Faculty of Education, Mahasarakham University, Thailand \\ Correspondence: Apantee Poonputta, Faculty of Education, Mahasarakham University, Thailand 44000.
}

Received: November 19, 2021

Accepted: December 30, $2021 \quad$ Online Published: January 6, 2022

doi:10.5539/jel.v11n2p43

URL: https://doi.org/10.5539/jel.v11n2p43

\begin{abstract}
The objectives of the research were: 1) to develop the lesson plans for "Weight and Measurement" of Mathematics by using Problem-Based Learning on TPACK MODEL based on the efficiency of the process and the overall result $\left(E_{1} / E_{2}\right)$ at the established criteria of $\left.75 / 75 ; 2\right)$ to compare the students' learning achievement in "Weight and Measurement" of the 1st grade students before and after by using Problem-Based Learning on TPACK MODEL; 3) to study the students' satisfaction with Problem-Based Learning on TPACK MODEL. The research samples were thirty-five 1st grade students of class 1 in the 1st semester of the academic year 2020 at Sanambin School in Khon Kaen Province. They were selected by purposive sampling. The instruments used in this study were lesson plans, an achievement test, and a questionnaire on students' satisfaction. The statistics used for analyzing the collected data were mean, standard deviation, percentage, and gain score. The research results showed that 1) the average efficiency of the lesson plans for "Weight and Measurement" by using Problem-Based Learning on TPACK MODEL with exercises was 85.54/78.71, which was higher than theestablished criteria. 2) The mean score of the 1st grade students for "Weight and Measurement" of Mathematics after using Problem-Based Learning on TPACK MODEL was significantly higher than that of before using the Problem-Based Learning Model. 3) The overall satisfaction of the students with the Problem-Based Learning on TPACK MODEL for "Weight and Measurement was at a high level.
\end{abstract}

Keywords: Problem-Based Learning, TPACK, primary school, achievement

\section{Introduction}

In the evolution of the human mind, mathematics plays a critical role. Make people more creative, think more rationally, think more systematically, and follow a pattern. Mathematics also provides for a complete study of a topic or scenario and aids in anticipating, planning, making decisions, and solving difficulties, as well as proper application in daily life. According to the Ministry of Education of Thailand (2008), children's learning is derived from process-based activities; content and activities are administered in accordance with the interests of the learners by having a combination of knowledge in various areas. Both academic content and life processes are morally organized and help students to think. Students can deal with and solve difficulties on their own, as well as collaborate with others. Its goal is to teach individuals how to think, act, and reach their full potential. Problem-based learning management, as defined by Dechakup and Yindeesuk (2014), is a teaching setting in which students are helped to reach their learning goals by using problems as a tool. The teacher may lead students to real-life problem situations, or the teacher may create an environment in which students can practice thinking, analyzing, and solving problems as a group. This will help students clearly understand the problem and see the other options. It also enhances a variety of strategies for dealing with problems as well as helping students build information and skills in thought cycles and critical thought actions (Khamanee, 2013). According to the State of Education Report of Thailand 2016/2017 (Office of the Education Council, 2018), the development results in education quality are not satisfactory. Because the results of the O-NET exam at the basic education level, 6th grade, 9th grade, and 12th grade in the 5 core subjects have not significantly changed over the last 5 years. The majority of them received less than a $50 \%$. As a result of the aforementioned issue, it should be designed to emphasize extensive and holistic learning. It is an opportunity to learn about real-world issues. Learning management should integrate thinking skills, problem solving, technology, and multimedia use, as well as real-world assessments that measure comprehension rather than content and students take part in self-evaluation. There are some connections and interactions between teachers and students, along with learners 
with learners at the same and different levels, including with the outside community (Office of the Education Council of Thailand, 2014; Panit, 2014). Regarding the outcomes, the integration of technology teaching methods and contents by using the TPACK model (Technological Pedagogical and Content Knowledge: TPACK) is really necessary in the classroom., Koehler and Mishra (2008) state that TPACK refers to the combination of technology, teaching methods, and the contents. It's the basic knowledge to understand technology-based teaching whenever the concept of contents is presentd by using technology (Koehler \& Mishra, 2008). Problem based learning (PBL) is a student-centered educational method which aims to improve problem-solving skills through a self-directed learning and team work skills (Ali, 2019). PBL helps students acquire a wide variety of generic skills such as communication, negotiation and problem-solving (Orfan, Akramy, Noori, \& Hashemi, 2021)

As a result, the researcher is keen to learn further about problem-based learning on content based on the TPACK MODEL. In this current study, the topic was weight measurement concept for the 1st grade as a good place to start, including how satisfied students are with the learning management. It is to improve teaching and learning for the benefit of students and to apply it to the management of mathematics learning subjects, particularly in the area of weight measurement.

\section{The Aims of the Study}

1) To develop the lesson plan on weight measurement matters of mathematic learning by using Problem-Based Learning (PBL) on TPACK MODEL with the efficiency of the process and the overall result $\left(\mathrm{E}_{1} / \mathrm{E}_{2}\right)$ at the established criteria of $75 / 75$;

2) To compare the students' learning achievement of the 1st grade students in "Weight and Measurement" before and after using Problem-Based Learning on TPACK MODEL;

3) To study the students' satisfaction with Problem-Based Learning on TPACK MODEL for "Weight and Measurement" of Mathematics.

\section{Method}

\subsection{Research Methodology}

Experimentel Research One Group Pretest Posttest Design (Fraenkel \& Wallen, 2008)

Table 1. One group pretest posttest design

\begin{tabular}{lll}
\hline $\mathrm{O}_{1}$ & $\mathrm{X}$ & $\mathrm{O}_{2}$ \\
\hline
\end{tabular}

Where,

$$
\begin{array}{ll}
\mathrm{O}_{1}: & \text { Pretest } \\
\mathrm{X}: & \text { using Problem-Based Learning on TPACK MODEL } \\
\mathrm{O}_{2}: & \text { Possttest }
\end{array}
$$

\subsection{Samples}

1) The population consisted of 326 primary school students at Sanambin School, Khon Kaen Province of the academic year 2020 .

2) The sample included thirty-five 1st grade students of class 1 at Sanambin School in the first semester of the 2020 academic year. They were selected by purposive sampling.

\subsection{Research Instrument}

1) Nine lesson plans for learning management

2) Fifteen items of a multiple-choice achievement test with three alternatives on "Weight and Measurement".

3) A questionnaire for the satisfaction of the students with Problem-Based Learning (PBL) and contents designed by the TPACK MODEL with three level. Interpret the mean as follows: Mean 2.51-3.00 High level, Mean 1.51-2.50 Moderate level and Mean 1.00-1.50 Low level.

\subsection{Data Collection}

1) The achievement test about weight measurement was used to before learning management.

2) According to the planned learning management plan, the researcher conducted Problem-Based Learning on 
TPACK MODEL, nine plans for learning management, lasting 3 weeks.

3) The achievement test was used to after implementing the lesson plans.

4) The assessment form was used to assess satisfaction with Problem-Based Learning on TPACK MODEL for "Weight and Measurement" of Mathematics of the students.

\subsection{Data Analysis}

The researcher analyzed the data as follows:

1) The efficiency of the learning activity plan of the processing performances $\left(E_{1}\right)$ and the performance results $\left(\mathrm{E}_{2}\right)$ by percentage, mean and standard deviation.

2) The achievement scores of the students for "Weight and Measurement" before and after using Problem-Based Learning (PBL) and contents designed by the TPACK MODEL were analyzed by percent of the progress of Ritcharoon formula (2013).

3) The satisfaction of the students with the TBL method and contents designed by the TPACK MODEL was analyzed by mean and standard deviation.

\section{Results and Discussion}

1) The efficiency of the problem-based learning management lesson plans based on the TPACK MODEL of "Weight and Measurement" for the 1st grade studnts was .85.54/78.71, which as shown was higher than the established criteria of 75/75 as showed in Table 2 .

Table 2. The results of the analysis of the effectiveness of the learning management plan

\begin{tabular}{llllll}
\hline Item & $\mathrm{N}$ & Total marks & $\mathrm{M}$ & $\mathrm{S}$ & $\%$ \\
\hline Process efficiency $\left(\mathrm{E}_{1}\right)$ & 35 & 60 & 51.33 & 7.80 & 85.54 \\
Overall result efficiency $\left(\mathrm{E}_{2}\right)$ & 35 & 20 & 15.74 & 3.33 & 78.71 \\
\hline
\end{tabular}

The results showed that the efficieny of the lesson plans for the problem-Based Learning and the contents designed by the TPACK MODEL of "Weight and Measurement" for the 1st grade students of class 1 regarding the process efficiency and the overall results efficiency was $85.54 \%$ and $78.71 \%$ respectively. The efficiency of the lesson pans was higher than the established criteria of 75/75.

2) The mean post-test score of the students was higher than that of pre-test score for 43.14 points as shown in Table 3.

Table 3. Comparison of the mean post-test score and pre-test score of the students after and before using the problem-Based Learning and the contents designed by the TPACK MODEL

\begin{tabular}{llllll}
\hline & The number of students & Pre scores (20) & Post scores (20) & Difference of scores & Percentage of a progress \\
\hline Total & 35 & 7.11 & 15.74 & 8.63 & 43.14 \\
\hline
\end{tabular}

The results indicated that the mean post-test score of the students was higher than that of pre-test score for 43.14 points after and before the Problem-Based Learning and the contents designed by the TPACK MODEL. The mean post-test score of the students was 15.74 points and the mean pre-test score of the students was 7.11 points.

3) The overall satisfaction of the students with the Problem-Based Learning and the contents designed by the TPACK MODEL was at a high level.

\section{Discussion}

The findings were summarized and discussed as follows

1) The efficiency of the lesson plans of "Weight and Measurement" designed by the Problem-Based Learning and the contents designed by the TPACK MODEL for the 1st grade students was higher than the established criteria of 75/75. The results may be caused by 5 steps of the Problem-Based Learning method consisting of 1) identifying problem, 2) investigating the inquiry process, 3) exploring the ideas and challenge them through collaborative activities, 4) utilizinf the inquiry process to refine products, and 5) Developing the summative product that addresses the challenge or problem \& publically share it. Kewara (2016) states that the teachers must consider the interests and needs of the students before design learning activities. The role of the teacher is not a 
speaker, but a facilitator. When students need for assistance with problems, the teacher must clarify and simplify the contents for the students. Rodkroh (2017) claims that problem-based learning is a form of instruction that can be used to improve the learning quality of primary school learners. The problem-based learning method provides students to develop analytical thinking, problem solving, decision making and creative thinking skills. Students have the opportunity to acquire knowledge independently and participate more in learning and practice while the teacher is only a facilitator, an advisor and an assistant to stimulat the students in thinking. Problem-based Learning or PBL is one of the best teaching models that can be used to improve the quality of learning of the elementary students. Problem-based learning enable students to develop critical thinking, problem solving, make decisions, and creative thinking. Additionnaly, problem-based learning provides students with the opportunity to seek self-directed learning resources and involve more in learning and practicing. Zakaria, Maat and Khalid (2019) asserted that problem-based learning had been used widely in different educational disciplines. The result showed that the achievement of the students in Mathematics improved significantly after using the problem-based learning method. The problem-based learning method was also used for Science, Chemistry, Engineering and English subjects. The results asserted that the PBL method had a positive effects on the learning achievement of the students. Additionnalt it enhanced the collaborative learning and inquiry learning skills of the students. The research results are consistent with those of Thepbamrung and Umkrai (2016). They studied a learning management of TPACK model using 3D augmented reality in science subject for grade 7 students case study in Bantonksadao school. The results showed that TPACK MODEL learning management with 3D augmented reality technique could increase the efficiency in developing science subjects for the 1 st grade students at $87.67 / 82.43$.

2) In the topic of "Weights Assessment", the previous learning performances of the students by using the framework of TPACK MODEL were significantly higher than the post ones at $43.14 \%$. Jathaisong, Boonchoo and Tangwangsakun (2017) asserted that the students' previous achievement in Mathematics, employing the problem-based learning, was significantly higher than the post ones at the 0.05 level. The results were consistent with the study of Srioudee (2018), who studied the development of science learning achievement for grade 5th students in Chumchon Bankhon School using problem-based learning, the findings revealed that the level in science learning achievement after doing taught using PBL were significantly higher than before at the statistical level of .05. Additionally, Kamphibal and Chamraspun (2021) asserted that the problem-based learning management had a significant effect on problem solving skills and learning achievement in Mathematics of 8th grade students. The findings indicated that the problems solving skills and learning achievement in Mathematics of the 8th grade students after using the problem-based learning method were significantly higher than those of the conventional method.

3) Regarding the students' satisfaction with problem-based learning management, community-based teaching and learning management, and language teaching by integrating language and contents based on the TPACK MODEL concept on "Weight Measurement", it was found that the students' satisfaction was at a high level. The results may be caused by the participation of the students in expressing their opinions during learning activities. The students were also encouraged to answer the questions and use English. As a result, the students were very satisfied with studies of Mathematics. Lertpanya (2019) asserted that the satisfaction of the preschool children with learning experiences designed by brain theory was at a high level. Additionally, Klomwong (2014); Jantamoka (2019), asserted that the students that learned by using the problem-based learning activities satisfied at high level.

\section{Suggestions}

\subsection{Suggestions for Practical Application}

The research found that the teaching and learning approach in collaboration with "Weight Measurement" in the 1st grade improved the higher academic achievement. The author proposes practical applications as follows:

1) Preparation in teaching, teachers should assess and develop previous knowledge and understanding of language skills of the students by training them to be ready for reading comprehension skills in understanding stories correctly and precisely.

2) Teachers should consider the appropriateness of contents based on the age and level of the learners because the PBL method is efficient and practical for training children to know how to analyze problems.

3) In making a group presentation, all groups of students should be presented in front of the class in order to realize the individaul differences and outcomes, including helping them correct the mistakes and solve the difficulties. 


\subsection{Suggestions for Further Study}

From the studies, the author discovered the troubles in hindering behaviors of the students. Therefore, the author has suggestions for further studies as as follows:

1) The PBL teaching method for "Weight Measurement" of primary school students is efficient and practical, it should be introduced and applied to teach other subjects such as geometry, length measurement, and related similar classes.

2) There should be various different methods for conducting further study on teaching "Weight Measurement".

3) The PBL method with TPACK MODEL should be adjusted appropriately to use in mathematical activities in other levels.

4) There should be comparative studies by using the problem-based and community-based teaching and learning and TPACK MODEL and other formats to be used in the mathematic instruction to improve learners' achievements.

\section{Acknowledgments}

This research project was financially supported by Mahasarakham University.

\section{References}

Ali, S. S. (2019). Problem Based Learning: A Student-Centered Approach. English Language Teaching, 12(5), 73-78. https://doi.org/10.5539/elt.v12n5p73

Dechakup, P., \& Yindeesuk, P. (2014). Learning Management in the 21st Century (2nd ed.). Bangkok: Printing house of Chulalongkorn University.

Fraenkel, J. R., \& Wallen, N. E. (2008). How to design and evaluate research in education (7th ed.). NY: MaGraw-Hill.

Jantamoka, T. (2019). A Comparison of Achievement and Mathematics Problem Solving Ability between Problem-Based Learning and Project-Based Learning. Mahasarakham: Mahasarakham University.

Jathaisong, K., Boonchoo, K., \& Tangwangsakun, W. (2017). A study Mathematics achievement by using problem-based learning for Grade 7 students. Kamphaeng Phet: Mathematics Program, Faculty of Education, Kamphaeng Phet Rajabhat University. Retrieved from https://edu.kpru.ac.th/math//contents/research/17.pdf.

Kamphibal, K., \& Chamraspun, U. (2021). The effect of Problem-based learning management on mathematics problem solving ability and learning achievement for mathauomsuksa 2 students. Journal of Graduate School, 18(80), 145-153. Retrieved from https://jgrad.snru.ac.th/ArticleView?ArticleID=210

Kewara, P. (2016). Learning English Through Content and Language Integrated Learning Type Approach: Concept and Perspectives for Thai Teachers. Journal of Education, 27(1), 28-40. Retrieved from https://drive.google.com/file/d/1C687j6tWsSCDhBdEKuWFGIfxv1VquCfu/view

Khamanee, T. (2013). Pedagogical Science: Knowledge for effective learning process management (17th ed.). Bangkok: Printing House of Chulalongkorn University.

Klomwong, P. (2014). The effects of problem-based learning activities on mathematical skills and processes in problem solving and learning achievement in probability of mathayomsuksa V students. Phitsanulok: Naresuan University.

Koehler, M. J., \& Mishra, P. (2008). Introducing Technological Pedagogical Content Knowledge. In AACTE Committee on Innovation and Technology (Ed.), Handbook of Technological Pedagogical Content Knowledge (TPCK) for Educators (pp. 3-29). New York: Routledge.

Lertpanya, M. (2019). Developing a model for organizing experiences based on brain theory as a learning base, combining the concept of using problems as a learning base to promote creativity of preschool children at kindergarten level 1 (pp. 573-584). NMCCON 2019, The 6th National Conference Nakhonratchasima College.

Ministry of Education of Thailand. (2008). Basic Education Core Curriculum 2008. Bangkok: Printing House. Agricultural Cooperative Association of Thailand Limited.

Office of the Education Council of Thailand. (2014). Guidelines for the development of Thai education and preparation for the 21st century. Bangkok: Office of the Education Council of Thailand. 
Office of the Education Council of Thailand. (2018). State of Thai education, 2016/2017. Problems on equality and quality of Thai education. Bangkok: Printing House of Chulalongkorn University.

Orfan, S. N., Akramy, S. A., Noori, A. Q., \& Hashemi, A. (2021). Afghan Lecturers' Perception of Problem-Based Learning: A Case Study of Takhar University. Journal of Problem-Based Learning, 8(2), 62-68. https://doi.org/10.24313/jpbl.2021.00059

Panit, P. (2014). Creating Learning for the 21st Century. Nakhon Pathom: Sor Charoen Printing Co., Ltd.

Ritcharoon, P. (2013). Classroom action research: Teachers are not difficult to do (10th ed.). Bangkok: House of Kermist.

Rodkroh, P. (2017). Problem-based Learning for Elementary students. Journal of Education, Silpakorn University, 15(2), 15-28. $\quad$ Retrieved from https://so02.tci-thaijo.org/index.php/suedujournal/article/view/174891

Srioudee, S. (2018). The Development of science learning achievement for grade 5th students in Chumchon Bankhon School using problem-based learning. Phitsanulok: Pibulsongkram Rajabhat University.

Thepbamrung, N., \& Umkrai, J. (2016). A learning management of TPACK model using 3D augmented reality in science subject for grade 7 students case study in Bantonksadao school. Journal of Project in Computer Science and Information Technology, 2(1), 29-35. Retrieved from http://it.rmu.ac.th/project-journal/downloads/entry/32

Zakaria, M., Maat, S., \& Khalid, F. (2019) A Systematic Review of Problem Based Learning in Education. Creative Education, 10, 2671-2688. https://doi.org/10.4236/ce.2019.1012194

\section{Copyrights}

Copyright for this article is retained by the author, with first publication rights granted to the journal.

This is an open-access article distributed under the terms and conditions of the Creative Commons Attribution license (http://creativecommons.org/licenses/by/4.0/). 